\title{
Effect of Career Development, Work Discipline and Work Environment to Job Satisfaction
}

\author{
Joko Bagio Santoso*, Yusuf Sidik \\ Department of Management \\ Sekolah Tinggi Ilmu Ekonomi Indonesia \\ Jakarta, Indonesia \\ *joko_bagio_santoso@stei.ac.id
}

\begin{abstract}
Career development of human resources in every organization become really important in increasing employee job satisfaction and organization performance in the future. Organization should endeavor to develop the level of job satisfaction by paying attention to their employee career. A supportive work environment and is supported by a good work discipline will help in increasing job satisfaction. The fact is, there are many employees with low levels of satisfaction and it has an impact on employee performance. This research aims to examine and find out the effect of career development, work discipline, and work environment to job satisfaction. The method of collecting data that is used for this research is using questionnaire and data analysis method using multiple correlation and determination coefficient. The results of research show that: (1) there is the effect of career development variable to job satisfaction. (2) There is the effect of work discipline variable to job satisfaction. (3) There is no effect of work environment variable to job satisfaction. (4) Simultaneously, career development, work discipline, and work environment affect to job satisfaction. The implication of this research is if the company wants to increase the job satisfaction, then the company should develop career, increase work discipline, and create a supportive work environment.
\end{abstract}

Keywords: career development, discipline work, environment work, job satisfaction

\section{INTRODUCTION}

Human resources are resources for competitive advantage for companies. The existence of a very tight competition between companies and technological advances, the role of human resources in determining the success of a company cannot be ignored. The success of an organization depends on the company's ability to manage the company's human resources. The company must always develop the career of its employees and create a good work environment so that the level of employee job satisfaction will increase. This needs to be supported by a disciplined attitude and employee behavior to support the organization's performance.

Employee job satisfaction depends on individual characteristics, work situation and work environment. Job satisfaction is a person's attitude towards his/her job. Job satisfaction means a feeling of pleased or displeased with the work situation, his/her colleagues and what is perceived by the person can be significantly positive or negative, depending on the perception of each employee. Job satisfaction refers to an individual's general attitude toward his or her job. A person with a high level of job satisfaction holds positive attitudes toward the job, while a person who is dissatisfied with his or her job holds negative attitudes toward the job [1].

This study aims to determine the effect of career development, work discipline and work environment to employee satisfaction at the Jakarta Cempaka Putih Islamic Hospital. The benefit of this research is to give the information to the organization or company about the importance of aspects of career development, work discipline and work environment to develop the employee performance that will impact on improving organizational performance. The results of this research are expected to be an additional information and knowledge in the field of human resource development.

With job satisfaction, an employee can feel his/her job. Fun job can be said that the job gives satisfaction. Job satisfaction as a pleasurable feeling that result from the perception that one's job fulfillment of one's important job values. Job satisfaction has a major contribution to increasing the morale of each employee. Job satisfaction includes all emotions and attitudes of the employees in relation to their work. Positive emotions and attitudes toward work constitute job satisfaction, and negative emotions and attitudes constitute job dissatisfaction [2]. Job satisfaction as the degree of an employee liking or disliking the work [3]. Job satisfaction is a positive attitude towards the work of employees and arises based on an assessment of the work situation [4]. Job satisfaction is the degree to which an individual feel positively or negatively about the various facets of the jobs, task, the work setting and relationship with co-worker. Job satisfaction is an emotional state that is pleasant or unpleasant in which employees view their works [5].

Career development is the process of identifying potential employee career and apply the proper ways to develop this potential. Career Development is a part of the HRD activity to help employees plan their future careers in the company so that the company and the employees concerned can develop themselves [6]. There are some indicators in developing career, which are: career needs, training, a wise treatment, career information, promotion, mutation, and labor development. 
Multiple correlation analysis is a form of correlation used

Being discipline while working is the factor that should be owned by the employees who want achieving satisfaction in their works. Work discipline can be about punctuality in working, being responsible to the assignments that are given to them and using facilities nicely. Discipline is an awareness and willingness of a person in being obedience to all the rules in the company and applicable social norms. A good discipline reflects how big is the responsible of a person to the assignments that are given to him/her [7]. The indicators which show that the employee has a discipline attitude are: being obedience to the time rules, institution rules, attitude rules, etc.

A good work environment either physically or nonphysically is being wished by employees to work maximally. If the environment is bad, the employees will not have satisfaction in working [8].

Some research results indicate that there is influence between career development, work discipline and work environment to employee satisfaction.

Based on the research results that were done by Mabruroh et al. [9], in Scientific Forum of Education and Accounting with title "Effect of Work Environment and Career Development to The Employees Job Satisfaction of Paru Dungus Hospital in Madiun" show that work environment has a significant effect to job satisfaction, while development career does not have significant effect to the employee's job satisfaction of Paru Dungus Hospital in Madiun. In the other research that the title is "Analysis of Job Embeddedness and Work Environment to Job Satisfaction and Employee Turnover Intentions at Siloam Hospital Manado " was conducted by Polii [10] showed that there was a significant positive effect between job embeddedness on job satisfaction, and there was a significant positive effect between work environment on job satisfaction. The next research was conducted by Ali et al. [11] with the title "Antecedents of Job Satisfaction a Case Study of Hospital's Employees of Pakistan". This study aims to measure job satisfaction in the Hospital and Health Sector of Pakistan. The results of this study stated that Career Development has a significant relationship with job satisfaction of Pakistan Hospital employees. Next research was conducted by Nemmaniwar and Deshpande [12] with the title "Job Satisfaction in Hospital Employees: A Review of Literature". It was found that other factors such as recognition, autonomy, achievement, opportunities for growth, and development correlated very positively with employee job satisfaction at the hospital.

\section{MethodS}

The data collection method used in this research is using questionnaire and data analysis method using multiple correlation and determination coefficient. This study uses a quantitative approach where the data that used include primary and secondary data. Primary data was obtained directly through questionnaires, direct observation and interviews. Secondary data were obtained from some written sources such as literature, articles, scientific papers or publications.

By using the Slovin formula, the number of samples used in this study were 193 non-medical employees at the Jakarta Cempaka Putih Islamic Hospital. to see the relationship between three or more variables (two or more independent variables and one dependent variable.

\section{RESULTS AND DISCUSSION}

\section{A. Descriptive Analysis}

There are the averages recapitulations of respondents score on each variables:

- Career development can be measured by using 7 indicators, based on the answers of the 193 respondents obtained that grand mean respondents score for career development variables is 2.67 and it's at interval 2-3 and it's included in the agreed category.

- Work discipline can be measured by using 4 indicators, based on the answers of the 193 respondents obtained that grand mean respondents score for work discipline variables is 2.78 and it's at interval 2-3 and it's included in the agreed category.

- Work environment can be measured by using 6 indicators, based on the answers of the 193 respondents obtained that grand mean respondents score for work environment variables is 2.69 and it's at interval 2-3 and it's included in the agreed category.

- Job satisfaction can be measured by using 9 indicators, based on the answers of the 193 respondents obtained that grand mean respondents score for job satisfaction variables is 2.87 and it's at interval 2-3 and it's included in the high agreed category.

\section{B. Data Quality Test}

1) Validity test: Based on the results of validity test on variables of career development, work discipline, work environment, and job satisfaction, seems like $\mathrm{r}$ count value is higher than the value of $r$ table that is equal to 0.141 so it can be said that the questions on the research variables are valid and can be used as research instruments.

2) Reliability test: Next, based on reliability test, result of reliability counting is Cronbanch Alpha obtained on variables of career development, work discipline, work environment, and job satisfaction is higher than 0.60 so it can be said that the questions on reliable reserach variable can be used as research instruments.

\section{Data Statistic Test}

1) Analysis of partial determination coefficient X1 against 
of determination of career development to job satisfaction is

TABLE I. PARTIAL CORRELATION OF CAREER DEVELOPMENT (X1) WITH JOB SATISFACTION (Y)

\begin{tabular}{|c|c|c|c|c|}
\hline \multicolumn{3}{|c|}{ Control Variable } & \multirow{2}{*}{\begin{tabular}{|c|}
$\begin{array}{c}\text { Career } \\
\text { Development }\end{array}$ \\
1 \\
\end{tabular}} & \multirow{2}{*}{\begin{tabular}{|l|} 
Job Satisfaction \\
0.525 \\
\end{tabular}} \\
\hline \multirow{6}{*}{$\begin{array}{l}\text { Work } \\
\text { Discipline \& } \\
\text { Work } \\
\text { Environment }\end{array}$} & \multirow{3}{*}{\begin{tabular}{|l|} 
Career \\
Development
\end{tabular}} & Correlation & & \\
\hline & & $\begin{array}{l}\text { Significance } \\
\text { (2-tailed) }\end{array}$ & 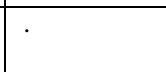 & 0.000 \\
\hline & & $\mathrm{Df}$ & 0 & 191 \\
\hline & \multirow{3}{*}{$\begin{array}{l}\text { Job } \\
\text { Satisfaction }\end{array}$} & Correlation & 0.525 & 1 \\
\hline & & $\begin{array}{l}\text { Significance } \\
\text { (2-tailed) }\end{array}$ & 0 & . \\
\hline & & $\mathrm{Df}$ & 191 & 0 \\
\hline
\end{tabular}

Based on the results of table 1, a partial correlation coefficient is obtained between the variables of career development with job satisfaction of 0.525 . So the coefficient value of career development determination to job satisfaction is $27.56 \%$ and the rest is $72.44 \%$ influenced by other variables. Y

\section{2) Analysis of partial determination coefficient X2 against}

TABLE II. PARTIAL CORRELATION OF WORK DISCIPLINE (X2) WITH JOB SATISFACTION (Y)

Correlation

\begin{tabular}{|c|c|c|c|c|}
\hline \multicolumn{3}{|c|}{ Control Variable } & $\begin{array}{c}\text { Work } \\
\text { Discinline }\end{array}$ & $\begin{array}{c}\text { Job } \\
\text { Satisfaction }\end{array}$ \\
\hline \multirow{6}{*}{$\begin{array}{l}\text { Career } \\
\text { Development } \\
\& \\
\text { Work } \\
\text { Environment }\end{array}$} & \multirow{3}{*}{$\begin{array}{l}\text { Work } \\
\text { Discipline }\end{array}$} & Correlation & 1 & 0.631 \\
\hline & & $\begin{array}{l}\text { Significance } \\
\text { (2-tailed) }\end{array}$ & . & 0.000 \\
\hline & & $\mathrm{Df}$ & 0 & 191 \\
\hline & \multirow{3}{*}{$\begin{array}{l}\text { Job } \\
\text { Satisfaction }\end{array}$} & Correlation & 0.631 & 1 \\
\hline & & $\begin{array}{l}\text { Significance } \\
\text { (2-tailed) }\end{array}$ & 0 & . \\
\hline & & Df & 191 & 0 \\
\hline
\end{tabular}

Based on the results of table 2, a partial correlation coefficient is obtained between the variables of work discipline with job satisfaction of 0.631 thus the coefficient of determination of career development to job satisfaction is $39.82 \%$. It can be concluded that the effect of work discipline on job satisfaction is $39.82 \%$, the rest is $60.18 \%$ influenced by other variables.

3) Analysis of partial determination coefficient X3 against $Y$

TABLE III. PARTIAL CORRELATION OF WORK ENVIRONMENT (X3) WITH JOB SATISFACTION (Y)

Correlation

\begin{tabular}{|c|c|c|c|c|}
\hline \multicolumn{3}{|c|}{ Control Variable } & \multirow{2}{*}{$\begin{array}{c}\begin{array}{c}\text { Work } \\
\text { Discipline }\end{array} \\
1\end{array}$} & \multirow{2}{*}{\begin{tabular}{l}
\multicolumn{1}{c}{$\begin{array}{c}\text { Job } \\
\text { Satisfaction }\end{array}$} \\
0.490
\end{tabular}} \\
\hline \multirow{6}{*}{$\begin{array}{l}\text { Career } \\
\text { Development } \\
\& \\
\text { Work } \\
\text { Environment }\end{array}$} & \multirow{3}{*}{$\begin{array}{l}\text { Work } \\
\text { Discipline }\end{array}$} & Correlation & & \\
\hline & & $\begin{array}{l}\text { Significance } \\
\text { (2-tailed) }\end{array}$ & . & 0.000 \\
\hline & & $\mathrm{Df}$ & 0 & 191 \\
\hline & \multirow{3}{*}{$\begin{array}{l}\text { Job } \\
\text { Satisfaction }\end{array}$} & Correlation & 0.490 & 1 \\
\hline & & $\begin{array}{l}\text { Significance } \\
\text { (2-tailed) }\end{array}$ & 0 & . \\
\hline & & Df & 191 & 0 \\
\hline
\end{tabular}

Based on the results of table 3 , a partial correlation coefficient is obtained between the variables of work environment with job satisfaction of 0.490 thus the coefficient
$24.01 \%$. It can be concluded that the effect of work discipline on job satisfaction is $24.01 \%$, the rest is $75.99 \%$ influenced by other variables.

4) Analysis of the coefficient of simultaneous determination

TABLE IV. COEFFICIENT OF SIMULTANEOUS DETERMINATION

\begin{tabular}{|c|c|l|l|c|}
\hline Model & R & R Square & Adjusted R Square & $\begin{array}{c}\text { Std. Error of the } \\
\text { Estimate }\end{array}$ \\
\hline 1 & $0.655^{\mathrm{a}}$ & 0.429 & 0.419 & 2.10667 \\
\hline
\end{tabular}

Based on table 4 the coefficient of simultaneous determination obtained between career development, work discipline, and work environment on job satisfaction is seen from the value of Adjusted R Square of 0.419 or $41.9 \%$, while the rest of $58.1 \%$ is influenced by other variables that are not examined in this research.

\section{Hypothesis Test}

\section{1) Simultaneous test (F Test)}

TABLE V. RESUlt OF SimultaneOUS TeSt

\begin{tabular}{|c|l|l|l|l|l|c|}
\hline \multicolumn{2}{|c|}{ Model } & $\begin{array}{c}\text { Sum of } \\
\text { Squares }\end{array}$ & \multicolumn{1}{|c|}{ Df } & $\begin{array}{c}\text { Mean } \\
\text { Square }\end{array}$ & F & Sig. \\
\hline \multirow{2}{*}{1} & Regression & 628.920 & -3 & 209.640 & 47.237 & $0.000^{\mathrm{b}}$ \\
\cline { 2 - 8 } & Residual & 838.790 & 189 & 4.438 & & \\
\cline { 2 - 7 } & Total & 1.467 .710 & 192 & & & \\
\hline \multicolumn{7}{|c|}{ a. Dependent Variable: Job Satisfaction } \\
\hline
\end{tabular}

Based on table 5, the calculated $F$ value of 47.237 with a probability of 0.000 while the results of the calculation at the $95 \%$ confidence level or $\alpha=0.05$, obtained $F$ table of 2.650 . This shows that F count (47.952) > F table (2.650), or sig. sig. $(0.000) \leq \alpha(0.05)$, so Ho is rejected and $\mathrm{Ha}$ is accepted. It can be concluded that simultaneous career development, work discipline and work environment affect to employee job satisfaction.

\section{2) Partial test}

TABLE VI. RESULT OF PARTIAL TEST Coefficients ${ }^{\text {a }}$

\begin{tabular}{|c|c|c|c|c|c|c|}
\hline & \multirow[b]{2}{*}{ Model } & \multicolumn{2}{|c|}{$\begin{array}{l}\text { Unstandardized } \\
\text { Coefficients }\end{array}$} & \multirow{2}{*}{$\begin{array}{c}\begin{array}{c}\text { Standardized } \\
\text { Coefficients }\end{array} \\
\text { Beta } \\
\end{array}$} & \multirow[b]{2}{*}{$\mathbf{T}$} & \multirow[b]{2}{*}{ Sig. } \\
\hline & & $B$ & Std. Error & & & \\
\hline \multirow[t]{4}{*}{1} & (Constant) & 13.186 & 1.164 & & 11.324 & 0.000 \\
\hline & \begin{tabular}{|l} 
Career \\
Development
\end{tabular} & 0.110 & 0.042 & 0.202 & 2.637 & 0.009 \\
\hline & \begin{tabular}{|l} 
Work \\
Discipline
\end{tabular} & 0.404 & 0.066 & 0.480 & 6.153 & 0.000 \\
\hline & $\begin{array}{l}\text { Work } \\
\text { Environment }\end{array}$ & 0.035 & 0.072 & 0.039 & 0.486 & 0.627 \\
\hline
\end{tabular}

a. Dependent Variable: $\mathrm{Y}$

Based on table 6 , the partial hypothesis test results:

a) The effect of career development on job satisfaction: Partial hypothesis test results, obtained a significant value on 


\section{ACKNOWLEDGMENT}

the career development variable of 0.009 , meaning that it is smaller than 0.05 so that $\mathrm{Ho}$ is rejected or $\mathrm{Ha}$ is accepted. Partially there is a positive and significant influence between career development variables and employee job satisfaction. It can be concluded that career development for employees will have a positive impact on job satisfaction.

b) The effect of work discipline to job satisfaction: Partial hypothesis test results, obtained a significant value on the work discipline variable of 0,000, meaning less than 0.05, so that $\mathrm{Ho}$ is rejected or $\mathrm{Ha}$ is accepted. Partially there is a positive and significant effect between the variables of work discipline with employee job satisfaction. It can be concluded that if employees have high work discipline, it will have a positive impact on job satisfaction.

c) The effect of work environment to job satisfaction: Partial hypothesis test results, obtained a significant value on the work environment variable of 0.627 , meaning greater than 0.05 so that Ho is accepted or Ha rejected. Partially there is no significant effect between work environment variables and employee job satisfaction.

\section{CONCLUSION}

Through this research, we can know some factors which can influence the job satisfaction. Those factors that affect that job satisfaction are career development, work discipline, and work environment.

The results of research show that: (1) there is the effect of career development variable to job satisfaction. (2) There is the effect of work discipline variable to job satisfaction. (3) There is no effect of work environment variable to job satisfaction. (4) Simultaneously, career development, work discipline, and work environment affect to job satisfaction.

The implication of this research is if the company want to increase the job satisfaction, then the company should develop career, increase work discipline, and create a supportive work environment.
This research was supported by Sekolah Tinggi Ilmu Ekonomi Indonesia (Indonesia College of Economics). We are thankful to our colleagues that provided expertise that greatly assisted the research, although they may not agree with all of the interpretations provided in this paper.

\section{REFERENCES}

[1] S.P. Robbins, Organizational Behaviour, Pearson Prentice Hall. New York, 2015

[2] M. Armstrong and S. Taylor, Handbook of Human Resource Management, Practice 13 ${ }^{\text {th }}$ ed. United Kingdom: Kogan Page, 2014.

[3] H.K. Ping and W. Yuan, "A Study on the Correlation between Working Pressure and Job Satisfaction from the Viewpoint of Work Exhaustion," Revista de Cercetare si Interventie Sociala., vol. 64, pp. 235-245, 2019.

[4] K. Davis and J.W. Newstrom, Organizational Behavior At Work, 11 ed. New York: Mc Graw -Hill, 2002.

[5] D. Sunyoto, Manajemen Sumber Daya Manusia. Yogyakarta: CAPS (Center Academic Publishing Service), 2012.

[6] A.P. Mangkunegara, Manajemen Sumber Daya Manusia Perusahaan. Bandung: PT Remaja Rosdakarya, 2016.

[7] M.S. Hasibuan, Manajemen Sumber Daya Manusia Edisi Revisi. Jakarta: PT Bumi Aksara, 2013.

[8] A. Khaidir, "Effect of Compensation and Work Environment on Employee Job Satisfaction at PT. Karya Mitra Muda," Manegement Journal, 2013.

[9] F. Mabruroh, Isharijadi and A.L. Wijaya, "Effect of Work Environment and Career Development to The Employees Job Satisfaction of Paru Dungus Hospital in Madiun," Forum Ilmiah Pendidikan Akuntansi, vol. 5, no. 1, 2017.

[10] L.R.G. Polii, "Analysis of job embeddedness and Work Environment to Job Satisfaction and Employee Turnover Intentions at Siloam Hospital Manado,” Jurnal EMBA, vol.3, no. 4, pp 178-190, 2015.

[11] M. Ali, M. Anis and A.Yadiv, “Antecedents Of Job Satisfaction A Case Study Of Hospital's Employess Of Pakistan,” International Journal of Economics, Commerce and Management, vol. 3, 2015.

[12] A.G. Nemmaniwar and M.S. Deshpande, "Job Satisfaction in Hospital Employees: A Review of Literature," International Journal International Journal of Engineering Technology Science and Research (IJETSR), vol. 4, 2017. 